\title{
Potret Hedonisme dalam Tiktok \\ (Analisis Khalayak pada Tiktok Sisca Kohl di Kalangan Remaja Kota Surabaya)
}

\author{
Potrait of Hedonism In tiktok \\ (Audience Analysis of Sisca Kohl's TikTok in Surabaya City \\ Teenagers)
}

Alifah Sabila1
Saifuddin Zuhri'
'Veteran' Jawa Timur
'22Fakultas Ilmu Sosial dan Ilmu Politik, Universitas Pembangunan Nasional
J1. Rungkut Madya No.1, Gn. Anyar, Surabaya, Jawa Timur 60294
alifahsabila98@ gmail.com

\section{Abstract}

Hedonism is a view that considers pleasure and material enjoyment as the main goal in life. The data shows that today's teenagers tend to be oriented towards a hedonistic lifestyle. In the hedonic lifestyle, humans are said to always prioritize happiness, but over time the interpretation of hedonism itself turns negative into pleasure in pursuing worldly and avoiding displeasure. This study focuses on how the acceptance of late adolescents in Surabaya regarding hedonism content in Sisca Kohl's TikTok. This research uses reception analysis method, Stuart Hall's encoding-decoding theory. Based on the results of the study, it was found that late adolescents in Surabaya with different backgrounds can be divided into three categories. The first category is Dominant Hegemonic Position, where they agree that there is an element of hedonism in Sisca Kohl's TikTok content and it has an impact on their lives. The second category is the Negotiated Code Position where they agree that there is an element of hedonism in Sisca Kohl's TikTok content, but there is 
no impact on their lives. The third category is the Oppositional Code where the informant rejects the element of hedonism displayed by Sisca Kohl in her TikTok.

Keywords: Hedonism, TikTok, Reception Analysis, Audience

\begin{abstract}
Abstraksi
Hedonisme adalah pandangan yang menganggap kesenangan dan kenikmatan materi sebagai tujuan utama dalam hidup. Data menunjukkan bahwa remaja saat ini cenderung berorientasi pada gaya hidup hedonisme. Dalam gaya hidup hedonis, manusia dikatakan selalu mengedepankan kebahagiaan namun seiring perkembangan zaman tafsir dari hedonisme sendiri berubah negative menjadi kenikmatan mengejar duniawi serta menghindari ketidaksenangan. Maka peneliti ingin mengetahui bagaimana penerimaan remaja akhir di Surabaya mengenai konten hedonisme dalam TikTok Sisca Kohl. Penelitian ini menggunakan metode analisis resepsi, teori encoding-decoding Stuart Hall. Berdasarkan hasil penelitian, didapatkan bahwa remaja akhir di Surabaya dengan berbeda latar belakang dapat dibedakan dalam tiga kategori. Kategori pertama Dominant Hegemonic Position, yaitu mereka menyetujui adanya unsur hedonisme dalam konten TikTok Sisca Kohl dan memiliki dampak di kehidupan mereka. Kategori kedua adalah Negotiated Code Position yang mana mereka menyetujui adanya unsur hedonisme dalam konten TikTok Sisca Kohl, namun tidak adanya dampak di kehidupan mereka. Kategori ketiga merupakan Oppositional Code dimana informan menolak adanya unsur hedonisme yang ditampilkan oleh Sisca Kohl dalam TikTok nya. Kata Kunci: Hedonisme, TikTok, Analisis Resepsi, Khalayak
\end{abstract}

\title{
I. PENDAHULUAN
}

Media sosial merupakan media baru yang banyak digunakan khalayak saat ini, karena lewat media social khalayak dapat melakukan percakapan dua arah secara efektif dan efisien. Media 
social juga digunakan oleh khalayak sebagai tempat untuk memberikan dan mendapatkan informasi, selain itu para pengggunanya bisa berinteraksi serta membentuk representasi diri, berkomunikasi, dan sebagainya sehingga membentuk ikatan sosial secara virtual. (Nasrullah, 2017)

Lembaga riset We Are Social mencatat bahwa selama 2020 ada sekitar 170 juta penduduk Indonesia yang merupakan pengguna media social aktif. Pengguna media social ini mencakup 61,8\% dari populasi penduduk di Indonesia yang berjumlah sekitar 274,9 juta orang. (Kemp, 2020)

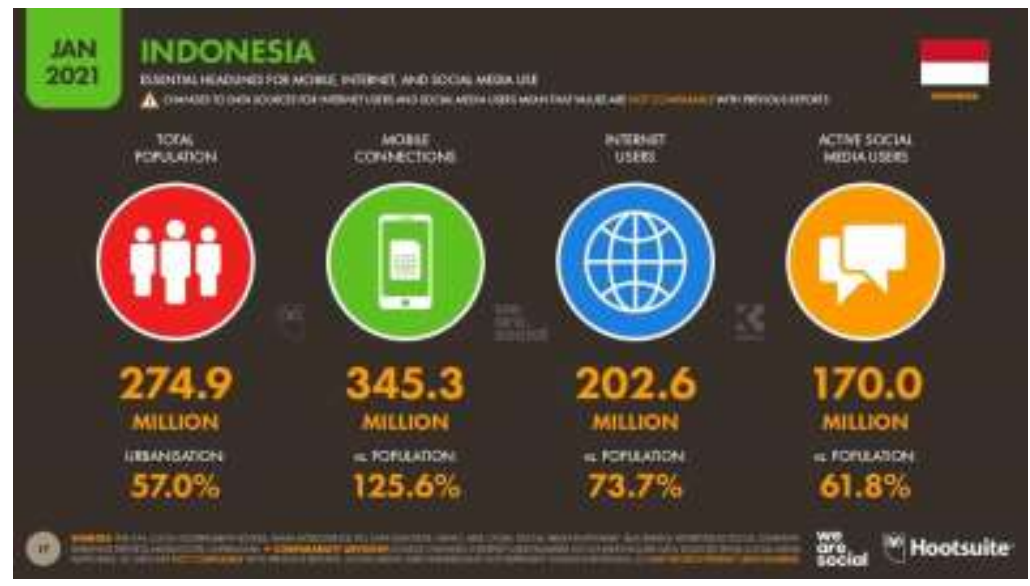

Sumber website www.wearesocial.com

Media sosial yang berkembang di Indonesia juga sangat beragam seperti Instagram, YouTube, Facebook, Twitter dan saat ini salah satu media social yang digemari masyarakat Indonesia adalah TikTok. Aplikasi video pendek asal China ini dapat merekomendasikan konten video yang diminati oleh 
penggunanya dengan algoritma canggih meliputi cara penggunanya menonton, berkomentar dan menyukai video-video yang ada di TikTok tersebut.

Pada 2018, TikTok sempat mengalami pemblokiran oleh Kominfo, TikTok dinilai melakukan banyak pelanggaran seperti konten pornografi, pelecehan agama serta konten-konten tidak mendidik lainnya. Namun, pihak kominfo memberikan penjelasan bahwa pemblokiran ini sifatnya sementara sampai pihak TikTok mematuhi ketentuan mengenai syarat konten di Indonesia (BBC, 2018). Tiktok kembali popular di Indonesia, Platform Store Intelligence milik Sensor Tower mencatat bahwa Indonesia masuk ke dalam Top 10 Countries for TikTok downloads. (Joe Tidy, 2020)

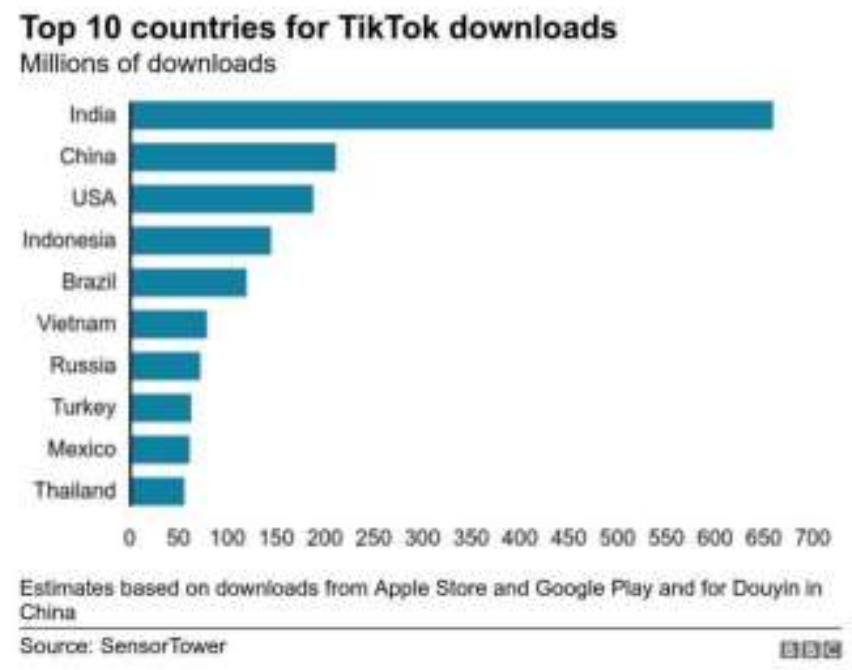

Sumber website: $\underline{w w w . b b c . c o m}$ 
Tiktok saat ini menjadi wadah bagi para content creator untuk menciptakan beragam video, mulai dari video dance cover, video tutorial masak, beauty and fashion seperti melakukan review skincare atau melakukan mix \& match pakaian, konten life hacks, konten rekomendasi barang, konten storytelling mengenai humor, bahkan konten edukasi kesehatan.

Head of User and Content Operations TikTok Indonesia, Angga Anugrah Putra mengatakan bahwa selama 2020 konten yang paling populer dikalangan masyarakat Indonesia adalah konten seputar komedi, edukasi, fashion, beauty, talent dan food. Bahkan banyak artis Indonesia yang kemudian mulai membuka account TikTok mereka seperti Vidi Aldiano, Yura Yunita, Inul Daratista, dsb. Selain itu banyak creator lainnya yang kontennya sering viral bahkan ditonton hingga jutaan masyarakat, salah satunya adalah creator muda bernama Sisca Kohl.

TikTokers bernama Sisca Kohl ini sempat viral dan menjadi perbincangan masyarakat karena konten-konten yang diunggahnya cukup kontroversial. Kontennya sering kali menampilkan tutorial masak dengan bahan-bahan tidak biasa, seperti es krim nasi padang, es krim boncabe dan sebagainya. Selain itu, Sisca kerap kali membuat konten review makanan mewah dan mahal yang berasal dari luar negeri seperti Durian Musangking, Truffle, Foie Gras bahkan Caviar. Tidak jarang pula ia menuliskan nominal makanan-makanan tersebut yang terbilang fantastis. Kontennya ini kerap mendapatkan jutaan penonton dan 
komentar, salah satu kontennya yang memiliki viewers sebanyak 44,5 juta viewers dan mendapatkan komentar sebanyak 3,7 juta. Konten ini berisi Sisca membongkar celengan masa kecilnya yang berisi ratusan juta rupiah beserta dua ponsel lamanya bermerk Vertu yang rilis pada 2018 asal Inggris dilansir dari artikel Kompas ditaksir harga ponsel tersebut adalah sebesar 86 juta rupiah. dan sempat sangat viral adalah ia membongkar celengan masa kecilnya yang berisi ratusan juta rupiah beserta dua ponsel lamanya bermerk Vertu yang rilis pada 2018 asal Inggris dilansir dari artikel Kompas ditaksir harga ponsel tersebut adalah sebesar 86 juta rupiah. (Rahmawati, 2021)

Konten pada media social seperti TikTok ini dapat memiliki efek yang sama dengan efek media massa seperti pengetahuan, emosi, sikap dan tingkah laku. Salah satunya adalaha konten TikTok Sisca ini, dimana Sisca kerap mengunggah video dengan konsep atau tema gaya hidup bermewah-mewahan atau bisa dikategorikan hedonisme di akun TikTok miliknya.

Hedonisme sendiri menjadi salah satu bentuk dari pemujaan terhadap kesenangan serta kenikmatan duniawi yang harus dikejar serta menjadi tujuan hidup bagi individu manusia (Nazry, 2019). Gaya hidup hedonisme memang mengandung kebenaran, yang mana manusia pada kodratnya selalu mencari kesenangan serta berupaya menghindari ketidaksenangan. Perilaku hedonis adalah bentuk dari pembuatan keputusan yang 
mana digunakan untuk memuaskan hasrat di luar pemenuhan kebutuhan utama seorang individu. (Mayasari, 2014)

Hedonis sebenarnya dianggap mengedepankan kebahagiaan, namun seiring dengan perkembangan zaman penafsiran hedonisme menjadi negatif yaitu mengutamakan kenikmatan yang cenderung bersifat mengejar duniawi dan sementara. Hedonisme bagi kalangan masyarakat yang mapan merupakan konstruksi ideologi pada saat mereka selalu mampu mendapatkan kepuasan dan memenuhi kebutuhan-kebutuhan (Soyomukti, 2010). Hedonisme di era globalisasi ini ditandai dengan munculnya aktivitas masyarakat global yang berlombalomba menunjukkan eksistensi dirinya dalam media sosial. Kaum hedonisme ini umumnya bertempat tinggal di kota-kota besar, dimana tidak adanya keterbatasan akses informasi serta berkecukupan untuk membiayai gaya hidup mereka.

Di Indonesia, terutama di kota-kota metropolitan seperti Jakarta, Bandung, Surabaya, Bali dsb tentu tidak asing dengan gaya hidup hedonisme. Terlebih, gaya hidup hedonisme ini cenderung dianut oleh remaja akhir atau dewasa awal dimana mereka masuk pada fase masa pencarian jati diri namun juga sudah dapat memutuskan bagaimana suatu hal. Sebuah penelitian menunjukkan bahwa Mall merupakan tempat paling popular dikalangan remaja, sedangkan prioritas utama para remaja ini adalah 'jajan' (49,4\%), jalan-jalan dan hura-hura (19,8\%), mengeluarkan uang untuk membeli pakaian $(2,3 \%)$ bahkan 
mereka juga membeli aksesoris mobil $(0,6 \%)$. Penelitian ini menunjukkan bahwa para remaja ini cenderung berorientasi pada gaya hidup hedonis saat ini. (Sosial et al., 2019)

Berdasarkan hasil pemaparan diatas, penelitian ini menarik untuk diteliti dalam hal penerimaan serta dampak di masyarakat terhadap unsur hedonisme yang dapat dikaji menggunakan analisis resepsi atau reception analysis.

Analisis resepsi merupakan perspektif serta pendekatan baru dalam sebuah penelitian khalayak media dan dalam aspek wacana-sosial dari teori komunikasi. Fiske menjelaskan bahwa pada reception analysis merupakan khalayak yang mencari makna lewat sebuah pesan teks media dimana makna yang disebutkan media sifatnya terbuka atau polysemic dan bahkan dapat ditanggapi secara oposisif oleh khalayak (Sely \& Aladdin, 2018).

Analisis resepsi ini merupakan tanggapan khalayak terhadap sebuah pesan, informasi ataupun karya. Bagaimana khalayak dalam menerima serta memahami objek yang diterima sehingga dapat diketahui mengapa khalayak memaknai atau memandang sesuatu pesan atau informasi secara berbeda, serta faktor-faktor apa yang mempengaruhi perbedaan tersebut. Analisis ini melihat pengaruh kontekstual dalam penggunaan media serta pemaknaan dari seluruh pengalaman khalayak.

Khalayak dilihat sebagai individu yang aktif dalam mempersepsi pesan serta memproduksi makna, khalayak tidak 
hanya sekedar menjadi individu pasif yang hanya menerima makna yang diproduksi oleh produsen. Khalayak diposisikan menjadi pihak yang mempunyai kekuatan untuk menciptakan makna secara bebas serta berperilaku sesuai dengan makan yang mereka ciptakan dari teks media tersebut. (Revia, 2019)

Stuart Hall menyatakan bahwa setiap orang memiliki kecenderungan yang berbeda-beda serta beragam ketika menginterpretasi pesan yang mereka terima, tergantung dari latar belakang budaya yang mereka ketahui. Maka, agar dapat memahami teks media tersebut perlu adanya kemampuan untuk mengartikan tanda beserta strukturnya. Hal ini menyebabkan tidak seluruh individu terpilih akan dapat memaknai hal yang sama dalam penerimaan teks media (McQuail, 2010). Hall juga memaparkan bahwa dalam analisis resepsi, penerimaan khalayak dapat dikategorikan dalam 3 kategori yang mana disebut sebagai Teori Encoding - Decoding.

Teori Encoding - Decoding mengidentifikasi 3 kategori penerimaan khalayak terhadap suatu kajian atau tayangan media, yaitu sebagai berikut:

\section{Dominan Hegemonic Position}

Khalayak dalam kategori ini sejalan dengan apa yang dikehendaki dalam sebuah tayangan media, atau khalayak setuju dan percaya dengan seluruh nilai-nilai dan tema yang disampaikan dalam sebuah tayangan atau pesan media.

2. Negotiated Code Position 
Pada kategori ini pesan media tidak bisa secara langsung diterima oleh masyarakat. Khalayak menerima sebuah tayangan atau pesan media tersebut namun jika ada pendapat berbeda makna khalayak memodifikasi makna yang diterimanya sedemikian rupa sehingga mencerminkan posisi serta minat pribadinya sesuai dengan interpretasi dan juga pengalaman tertentu yang mereka alami.

\section{Oppositional Code}

Pada kategori ini khalayak memahami isi atau makna pesan dari produk media, namun khalayak memiliki interpretasi yang tidak sejalan atau berbeda terhadap isi pesan media tersebut. (Idham, 2019)

Penelitian ini akan berfokus kepada remaja akhir atau late adolescent (18-22th) yang mana pada kategori ini remaja cenderung bisa mengendalikan emosinya serta memikirkan segala konsekuensi yang dapat ia hadapi dalam suatu perbuatan. Remaja juga cenderung mulai memahami apa yang dikehendakinya tanpa mengikuti kehendak orang lain. Kestabilan emosi dan kemandirian cenderung didapatkan oleh remaja pada tahap ini. (Dr. Hendriati Agustiani, 2009)

Remaja akhir ini difokuskan di kota Surabaya sebagai kota metropolitan yang heterogen yaitu memiliki beragam penduduk dengan berbagai macam latar belakang suku, ras serta agama. Hal ini dapat menimbulkan beragam respon mengenai gaya hidup hedonisme pada konten TikTok Sisca Kohl, yang 
mana pandangan atau gagasan masing-masing individu tentu saja berbeda dalam menerima konten tersebut. Beberapa remaja di Surabaya akan dipilih peneliti dengan metode purposive sampling dengan mempertimbangkan latar belakang yang dimiliki masingmasing informan guna menyesuaikan keragaman data dan kepentingan dari penelitian ini.

\section{METODOLOGI PENELITIAN}

\section{A. Jenis Penelitian}

Metode yang digunakan dalam penelitian ini adalah deskriptif kualitatif dengan pendekatan analisis resepsi model encoding/decoding Stuart Hall untuk mengetahui penerimaan remaja di Surabaya dengan berbagai macam latar sosial-ekonomi berbeda dalam "konten TikTok Sisca Kohl" menggunakan metode wawancara atau in-depth interview dengan informaninforman yang telah ditentukan oleh peneliti.

\section{B. Pengumpulan Data}

Informan dalam penelitian ini dipilih dengan teknik pengumpulan informan W. Lawrence Naeuman, yaitu menggunakan purposive sampling yang mana teknik pengambulan sampel pasa sumber data dengan pertimbangan tertentu. (Sugiyono, 2016)

Maka dari itu peneliti memilih informan sesuai dengan kriteria tertentu, yaitu sesuai dengan topik penelitian serta dinilai kredibel dalam menjawab permasalahan penelitian. Dalam penelitian ini telah ditentukan bahwa kriteria informan harus 
remaja akhir berusia antara 18-22 tahun dengan 3 kategori kondisi ekonomi yang berbeda-beda. Menurut Boston Consulting Group, ada proyeksi kelas sosial masyarakat Indonesia yaitu menengah ke atas (upper middle) dengan pengeluaran bulanan >Rp.3.000.000, menengah (middle) dengan pengeluaran Rp.2.000.000 - Rp.1.000.000 dan menengah ke bawah (poor middle) yaitu <Rp.1.000.000. (Yuliyati, 2020)

Para remaja akhir ini berdomisili di Surabaya, mengetahui konten Sisca Kohl minimal 3 postingan yang telah di-upload Sisca Kohl yang berjudul "Nasi Goreng Rp. 500.000.000”, "Boba Rp 300.000.000" dan "Sosis Sultan Topping Truffle dan Caviar Rp. 50.000.000".

Metode pengumpulan data dari informan dengan kriteriakriteria yang sudah ditetapkan tersebut adalah sebagai berikut:

1. Wawancara

Peneliti melakukan wawancara mendalam (in-depth interview) terhadap informan yang sudah ditetapkan sesuai kriteria penelitian serta kredible dalam memberikan jawaban terkait penelitian.

2. Observasi

Pengamatan dilakukan dengan mengamati objek secara langsung tanpa mediator. Beberapa informasi yang bisa diperoleh menggunakan teknik observasi adalah ruang (tempat), kegiatan, objek, pelaku, perbuatan, kejadian atau peristiwa, waktu serta perasaan. 
3. Dokumentasi

Metode dokumentasi ini menunjang pengumpulan data dari teknik wawancara dan observasi berupa rekaman audio maupun video yang berkaitan dengan proses wawancara ataupun observasi.

\section{PEMBAHASAN}

\section{A. Profil Informan}

Peneliti telah memilih 8 orang sebagai informan penelitian ini, ke-8 informan ini dipilih berdasarkan kriteria yang telah ditentukan oleh peneliti yaitu remaja akhir (late adolescent) usia sekitar 18-22 tahun, berdomisili di Surabaya, masuk ke dalam 3 kategori kelas sosial yang ada serta mengetahui konten TikTok Sisca Kohl.

\begin{tabular}{|c|l|l|l|}
\hline No. & Nama & Usia & Kelas Sosial \\
\hline 1. & Alvin Mifta & 22 th & Poor Middle \\
\hline 2. & Donna Zulfa & 22 th & Upper Middle \\
\hline 3. & Aulia Putri & 20 th & Middle \\
\hline 4. & Aisyah Fadhilah & 22 th & Poor Middle \\
\hline 5. & Margaretha Hefina & 22 th & Middle \\
\hline 6. & Rinne Indranto & 22 th & Middle \\
\hline 7. & Thierry Rayhan & 19 th & Poor Middle \\
\hline 8. & Intan Trisnadewi & 21 th & Upper Middle \\
\hline
\end{tabular}

Tabel 1. Informan Penelitian 
Para informan di atas akan melewati tahapan wawancara atau in-depth interview dengan mengajukan pertanyaanpertanyaan yang mana jawaban dari para informan ini bisa dapat digolongkan oleh peneliti ke dalam tiga model kategori pada teori encoding-decoding milik Stuart Hall, Dominant Hegemonic, Negotiated Code Position, dan Oppositional Code.

\section{B. Dominan Hegemonic Position}

Informan yang masuk ke dalam kategori Dominant Hegemonic ini merupakan informan-informan yang menyetujui jika konten Sisca Kohl ini memperlihatkan atau mengandung unsur hedonisme yang kuat.

Informan 1 - Alvin, seorang freshgraduate yang baru saja bekerja dengan pengeluaran bulanan <Rp.1.000.000 (poor middle) mengatakan bahwa menurutnya konten berunsur hedonisme dalam konten TikTok Sisca Kohl layak dan wajar saja untuk diunggah dan dikonsumsi oleh masyarakat, "menurut saya sih layak-layak aja ya, kadang kontennya juga menghibur jiwa kemiskinan saya hahahaa. Tapi ya balik lagi sih gimana kita nyikapinnya aja, selain itu gak masalah lagi karna itu dia kan pake harta atau uangnya sendiri ya buat bikin konten, jadi ya menurut saya fine-fine aja". Selain itu Alvin juga mengatakan bahwa adanya dampak yang ditimbulkan setelah menonton konten TikTok Sisca Kohl, "sebenernya sih yang pasti pengen kaya raya kayak dia ya hhahaaha, siapa yang gak pengen kaya raya...itu menurut saya hal yang wajar sih. Saya pengen juga 
makan truffle dan caviar apalagi ya itu yang mahal-mahal. Bikin termotivasi sih cuma ya agak susah kayanya hahaha"

Informan 6 - Rinne, Mahasiswi Komunikasi tingkat akhir yang juga bekerja sebagai tim kreatif dari salah satu fashion brand di Surabaya juga menyatakan bahwa TikTok dari Sisca Kohl memang mengandung unsur hedonisme "kuat banget, karna banyak banget hal-hal yang gak penting atau kegiatan ngabisin uang ke hal-hal gak penting yang dilakuin sama Sisca. Soalnya kan menurutku hedonisme itu menghambur-hamburkan uang buat hal-hal gak penting kaya gitu, ya itu pokoknya kontennya dia penuh kegiatan hedon". Rinne juga menambahkan bahwa konten TikTok Sisca Kohl cukup membawa dampak di dirinya karena menurutnya kehidupan Sisca terlihat mudah jika ingin sesuatu, "kalo pengen jadi dia ya pengen sih, soalnya kok terlihatnya semuanya mudah buat dia terus rumahnya bagus, kamarnya bagus, barang-barangnya bagus siapa gak kepengen $y a \ldots "$

Informan 8 - Intan, seorang yang bekerja dalam bidang research and development salah satu perusahaan kreatif menyatakan bahwa unsur hedonisme yang ditampilkan oleh Sisca Kohl memang sangatlah kuat, "aku liat kontennya aja langsung mikir hedon banget nih orang, kontennya tuh beneran agak mindblowing sih, kalo dipikir-pikir ya ngapain juga orang jualan nasi goreng 500 juta...tapi ya dia mampu sih kayanya kalo beneran beli nasi goreng 500 juta". Intan yang termasuk dalam 
kategori kelas sosial upper middle ini juga memberikan pernyatan jika ada dampak yang ditimbulkan setelah ia menonton konten TikTok Sisca Kohl, terutama ketika Sisca menyorot bagian uangnya yang tidak sedikit itu, "first impression ya pasti langsung mikir ya ampun enak bgt ya jadi dia jadi pengen, apalagi pas liat uang segebok-segeboknya itu. Meskipun ya kalo aku jadi dia aku tetep gamau sih beli nasgor 500 juta, tapi kalo punya duit banyak kaya dia mau lah"

Ketiga informan (informan 1,6 dan 8) yang termasuk ke dalam kategori ini sama-sama menyetujui bahwa adanya unsur hedonisme dalam konten TikTok Sisca Kohl. Selain itu mereka juga memaparkan bahwa adanya dampak yang ditimbulkan setelah menonton konten TikTok tersebut adalah adanya rasa ingin memiliki gaya hidup mewah seperti yang ditampilkan Sisca Kohl.

\section{Negotiated Code Position}

Kategori kedua adalah para informan yang masuk ke dalam Negotiated Code Position, dalam kategori ini informan menyetujui unsur hedonisme dalam konten TikTok Sisca Kohl ini sangat kuat, namun konten-konten Sisca Kohl ini tidak membawa pengaruh atau dampak di kehidupan sehari-harinya.

Informan 2 - Donna, remaja akhir berumur 22 tahun dan sudah bekerja selama 2 tahun menjadi banker dengan pengeluran bulanan di atas 3 juta (upper middle). Donna menyetujui bahwa 
konten TikTok Sisca Kohl ini memang menunjukkan unsur hedonisme, "menurutku sih ya kalo diliat-liat emang Sisca ini kaya raya dari awal, kayak nya dia gak butuh uang dari kontennya. Terus mungkin dia kebanyakan uang jadi gak tau uangnya harus diapain dan dia pinter sih buat tenarnya...dia bikin konten yang mana orang-orang tuh gak bisa relate sama kontennya dia ya hedonisme itu dan ya beneran kan dia booming, viral banget jadinya dia makin terkenal dan makin eksis dimanamana". Namun Donna mengatakan bahwa konten TikTok Sisca Kohl ini tidak membawa pengaruh apa-apa dalam kehidupannya, "Kalo dari sisi liat kontennya Sisca Kohl sendiri aku gak pernah terpengaruh atau pengen jadi kayak dia ya, karna pun sebelum liat dia aku juga udah pengen jadi orang kaya raya hahahha jadi menurutku tanpa ngelihat Sisca Kohl akupun pengen kaya raya, pengen financialy stable"

Informan 3 - Aulia, seorang Mahasiswi berumur 20 yang memiliki pengeluaran antara 1-2 juta perbulannya atau termasuk kelas sosial masyarakat kategori middle. Aulia menyetujui bahwa unsur hedonisme yang kuat dalam konten TikTok Sisca Kohl "Sudah pasti iya hahaha mungkin karna semua konten nya yang diangkat itu mengandung nilai materi yang cukup besar. Sering nyebutin nominal kan dia, nah itu nominalnya gak dikit”. Aulia juga berpendapat bahwa konten Sisca Kohl ini tidak berdampak apapun dalam kehidupannya karena ia merasa hal-hal yang dilakukan oleh Sisca tidak menarik untuk dirinya, "Sejauh ini 
nggak ada sih yaa untungnya kalo rasa ingin memiliki barang atau bikin hal-hal aneh kaya dia. Gak tertarik aja aku”

Informan 4 - Aisyah, seorang freshgraduate berumur 22 tahun dengan pengeluaran bulanan dibawah 1 juta atau termasuk poor middle. Aisyah mengatakan bahwa memang konten TikTok Sisca Kohl mengandung unsur hedonisme, "Jelas mengandung unsur hedonisme, hampir di semua kontennya diperlihatkan makanan dalam jumlah yang sangat banyak yang otomatis juga punya nilai materi yang tinggi padahal dalam videonya dia nggak makan semua makanan yang ditampilkan, dalam kata lain dia cuma menunjukkan kemampuan dia yang bisa membeli makanan-makanan yang mahal dan dalam jumlah banyak tersebut”. Aisyah juga menyebutkan bahwa ia tidak terpengaruh oleh konten-konten hedonisme milik Sisca Kohl dikarenakan ia merasa bahwa hal-hal yang ia lihat sosial media hanyalah sebuah konten \& hiburan untuknya, "Saya tipe orang yang nggak gampang terpengaruh sama terpaan konten-konten di media sosia sih, soalnya saya cuma ngeliatnya sebatas untuk hiburan"

Informan 5 - Margaretha, seorang Mahasiswi semester akhir yang juga bekerja menjadi barista kopi dengan pengeluaran sebesar 1-2 juta rupiah (middle) perbulannya, mengatakan ia juga menyetujui bahwa konten Sisca Kohl mengandung unsur hedonisme, "iyaaa kuat, karna ya setiap kontennya ada unsur materinya kaya harga nasi goreng 500 juta lah, pake caviar lah dan itu harganya kaya gak masuk akal banget kan? Pokoknya 
dalam jumlah yang banyak gitu deh produk-produk yang ditampilin di kontennya, menurutku itu termasuk hedonisme juga sih soalnya barangnya berlebihan banget kalo di kontennya". Margaretha juga mengatakan bahwa konten TikTok Sisca tidak membawa pengaruh apa-apa karena tidak sesuai dengan standart hidupnya, "yaa biasa ajaaa, gak terpengaruh karna emang itu gak sesuai sama kehidupanku...Ya Allah itu kaya banget hhahaha mangkannya dia bisa bikin konten kaya gitu...jadi apa ya, aku melihat itu konten doang gak boleh iri berlebih"

Para informan yang masuk ke dalam kategori ini berjumlah 4 orang (informan 2,3,4,5) mereka juga menyatakan bahwa konten TikTok Sisca Kohl memang memiliki unsur hedonisme. Namun, ke-4 informan ini menyebutkan bahwa konten TikTok Sisca Kohl tidak memiliki dampak apa-apa pada mereka dengan alasan berbeda-beda. Salah satunya informan 2, Donna yang mana ia termasuk kategori individu dengan kelas sosial menengah ke atas atau upper middle, mengatakan bahwa sebelum menonton TikTok Sisca Kohl pun ia sudah ingin menjadi orang berkecukupan atau kaya raya.

\section{Oppositional Code}

Kategori ketiga adalah oppositional code dimana para informan ini menolak adanya unsur hedonisme yang ditampilkan oleh Sisca Kohl dalam TikTok nya.

Informan 7 - Thierry, remaja akhir berumur 19 tahun ini merupakan Mahasiswa jurusan Teknik dengan pengeluaran 
bulanan di bawah 1 juta atau termasuk kategori kelas sosial poor middle. Thierry memberikan pernyataan bahwa konten Sisca Kohl tidaklah mengandung unsur hedonisme, "Menurut saya tidak, Sisca Kohl dapet feedback berupa engagement serta finansial yang didapat dari sosial medianya kan ya mbak, dan menurut saya feedback yang didapat Sisca Kohl ini worth dengan apa yg dia keluarkan gitu sih”. Selain itu Thierry juga menambahkan bahwa dari konten TikTok Sisca Kohl, penilaian masyarakat Indonesia dalam bermain sosial media dapat ditentukan, "lewat konten nya Sisca ini menurut saya ya kecerdasan masyarakat berperilaku di sosial media bisa di tes. Mereka niru hal-hal gak masuk akal begitu apa gak”.

Informan ke-7 ini masuk ke dalam kategori oppositional code karena ia dengan jelas menolak atau menerima bahwa konten TikTok Sisca Kohl mengandung unsur hedonisme dengan alasan bahwa sejumlah materiil yang dikeluarkan Sisca Kohl dalam kontennya sebanding dengan engagement yang di dapatkan oleh Sisca.

\section{KESIMPULAN DAN SARAN}

\section{A. Kesimpulan}

Dari hasil pembahasan di atas, peneliti dapat menyimpulkan bahwa gaya hidup hedonisme dalam konten TikTok Sisca Kohl tidak sepenuhnya diterima dengan makna yang sama oleh masing-masing khalayak. 3 informan berada 
dalam kategori dominan hegemonic, 4 orang berada dalam posisi negotiated code position, dan 1 orang berada dalam kategori oppositional code. Perbedaan penerimaan serta dampak yang timbul dalam pernyataan setiap individu informan diakibatkan oleh perbedaan latar belakang, baik dari segi pendidikan, gaya hidup, jenis kelamin, usia, kelas sosial, dsb.

\section{B. Saran}

Setelah penelitian ini dilakukan, pada dasarnya penelitian ini hanyalah berfokus mengenai penerimaan khalayak serta dampak yang ditimbulkan terhadap unsur hedonsime yang ditunjukkan Sisca Kohl dalam konten TikTok nya. Maka diharapkan penelitian ini dapat menjadi pelengkap bagi penelitian-penelitian selanjutnya mengenai hedonisme atau media sosial lainnya dengan menggunakan metode penelitian lain. Peneliti juga berharap penelitian-penelitian selanjutnya dapat menghasilkan analisis yang komprehensif mengenai hedonisme yang ditampilkan dalam media sosial.

\section{DAFTAR PUSTAKA}

Dr. Hendriati Agustiani. 2009. Psikologi Perkembangan:

Pendekatan Ekologi Kaitannya Dengan Konsep Diri dan Penyesuaian Diri Remaja.

Idham, H. 2019. Analisis Resepsi Khalayak Terhadap Gaya Hidup Clubbing Yang Ditampilkan Melalui Foto Dalam 
Akun Instagram @ INDOCLUBBING Idham Hawari Mahasiswa Program Studi Ilmu Komunikasi , Fakulas Ilmu Sosial dan Ilmu Politik, Universitas Airlangga. 1-11. http://repository.unair.ac.id/id/eprint/87292

Mayasari, I. 2014. PERILAKU HEDONIS Pandangan Teoretis dan Praktis (A. Tito (ed.)). Nida Dwi Karya.

McQuail, D. 2010. Teori Komunikasi Massa. Jakarta: Salemba.

Nasrullah, R. 2017. Media Sosial: Perspektif Komunikasi, Budaya, dan Sosioteknologi. Bandung: Simbiosa Rekatama Media (Vol. 3, Issue 1).

Nazry, M. A. A. A. 2019. Refleksi Fenomena Gaya Hidup Hedonisme Pada Akun Instagram (Studi Pada Mahasiswa Fakultas Ekonomi Dan Bisnis Universitas Syiah Kuala). Jurnal Ilmiah Mahasiswa FISIP Unsyiah, 4(4), 1-12.

Rahmawati, F. 2021. Mengenal Sisca Kohl, TikTokers yang Viral Usai Bongkar Celengan dan Bikin Es Krim Nasi Padang. 20 Maret. https://www.kompas.tv/article/157033/mengenalsisca-kohl-tiktokers-yang-viral-usai-bongkar-celengan-danbikin-es-krim-nasi-padang? page $=3$ 
Revia, B. 2019. Penerimaan Khalayak mengenai Gaya Hidup Hedonisme yang ditampilkan dalam Video Blog NRab Family. Jurnal Komunikatif, 8(1), 99-120. https://doi.org/10.33508/jk.v8i1.2069

Sely, T., \& Aladdin, Y. A. 2018. Analisis Resepsi Pembaca Tribunnews.com Dari Kalangan Mahasiswa/I Universitas Indonesia Terhadap Insiden "Kartu Kuning" Ketua BEM UI. Jurnal SEMIOTIKA, 12(1), 62-72.

Sosial, F. I., Politik, I., Memenuhi, U., Guna, P., Gelar, M., \& Sosial, S. 2019. Potret Gaya Hidup Hedonis Di Kalangan Mahasiswa (Studi Kasus: Mahasiswa FISIP UIN Syarif Hidayatullah Jakarta angkatan 2014 - 2016) SKRIPSI.

Soyomukti, N. 2010. Membongkar Aib Seks Bebas \& Hedonisme Kaum Selebriti (Mathori A. Elwa dan Irwan Kurniawan (ed.)). PENERBIT NUANSA CENDEKIA.

Sugiyono. 2016. Metode Penelitian Kualitatif dan Pembelajaran. Alfabeta, 1(1), 1-99.

Yuliyati, E. 2020. Implementasi Manajemen Peserta Didik Kelas Menengah Muslim di SMP IT Bina Umat Yogyakarta. 
Dirasat: Jurnal Manajemen Dan Pendidikan .... https://mail.journal.unipdu.ac.id/index.php/dirasat/article/do wnload/1963/1025

Website

BBC. 2018. Kenapa Aplikasi Tik Tok Diblokir Pemerintah? Www.Bbc.Com. https://www.bbc.com/indonesia/trensosial44693331

Joe Tidy. 2020. TikTok: What is the app and how much data does it $\quad$ collect? $? \quad B B C \quad$ News. https://www.bbc.com/news/technology-53476117

Kemp, S. 2020. Hootsuite (We are Social): Indonesian Digital Report 2020. Global Digital Insights, 247. https://datareportal.com/reports/digital-2020-indonesia 